\title{
BM] Global Health How food and beverage companies leveraged the great recession: lessons for the COVID-19 pandemic
}

\author{
Melissa Mialon (D ,,$^{1}$ Ilana Pinsky, ${ }^{2}$ Laura Schmidt (D) ${ }^{3}$
}

To cite: Mialon M, Pinsky I, Schmidt L. How food and beverage companies leveraged the great recession: lessons for the COVID-19 pandemic. BMJ Global Health 2021;6:e007146. doi:10.1136/ bmjgh-2021-007146

Handling editor Seye Abimbola

Received 9 August 2021

Accepted 17 September 2021

Check for updates

(c) Author(s) (or their employer(s)) 2021. Re-use permitted under CC BY-NC. No commercial re-use. See rights and permissions. Published by BMJ.

${ }^{1}$ Trinity College Dublin, Dublin, Ireland

${ }^{2}$ CUNY City College, New York, New York, USA

${ }^{3}$ University of California San Francisco, San Francisco, California, USA

Correspondence to Dr Melissa Mialon; melissa_mialon@hotmail.fr
The COVID-19 pandemic might present opportunities for transnational food and beverage companies to further consolidate their power within global markets. ${ }^{12}$ Some companies, for example, seem to be currying favour of governments, civil society organisations and communities by handing out free ultraprocessed products to the food insecure through heavily branded philanthropic initiatives. ${ }^{3}$ Other companies have used the pandemic to forge stronger alliances with government and civil society actors, which may water down or even silence criticism about the negative health impacts resulting from the consumption of their products, particularly ultraprocessed ones. ${ }^{3}$ This was epitomised by the WHO Foundation's recent decision to accept funding from Nestlé, despite Nestlé's ongoing breaches of the WHO Code of Marketing of Breastmilk Substitutes. ${ }^{4}$ The company's donations for COVID-19 aid even got a 'thank you' from WHO on social media. ${ }^{5}$

One need look no farther than the last global crisis, the 2007-2008 Great Recession, to understand the food and beverage industry's behaviour during the COVID-19 crisis. It is notable that the top three publicly traded food and beverage companies emerged from the Great Recession more globally dominant than before it. The Coca-Cola Company reported \$28857million in 2007 revenues compared with \$46542million in 2012 (inflation-adjusted US dollar). Moreover, PepsiCo reported $\$ 39474$ million in 2007 and $\$ 66504$ in 2012. ${ }^{6}$ Meanwhile Nestlé maintained its revenues while consolidating its position as the global market leader. ${ }^{6}$

Our examination of 66 company reports (annual reports and corporate social responsibility reports) and documents (such as those posted on the United Nations Global Compact website) from Coca-Cola, PepsiCo and Nestlé reveals that they used common
Summary box

- The COVID-19 pandemic presents opportunities for transnational food and beverage companies to further consolidate their power within global markets.

- The top three food and beverage companies, CocaCola, PepsiCo and Nestlé, emerged from the Great Recession more globally dominant than before it.

- Food and beverage companies leveraged economies in low-income and middle-income countries, which experienced more limited impacts from the Great Recession, and positioned themselves as partners to government and civil society.

- Transnational food and beverage companies appear to be deploying similar strategies since the beginning of the COVID-19 pandemic.

and successful strategies for leveraging the Great Recession.

First, all three companies leveraged the Great Recession to deepen corporate incursion into low-income and middle-income countries (LMICs)..$^{7-9}$ These companies emphasised that the crisis increased the prices of raw materials and volatility in national currencies, and undermined consumer confidence and purchasing power, thus leading to decreased demand for food products. ${ }^{8}{ }^{10}$ However, compared with other economic sectors, foods and beverages were appreciated as staple commodities, as Coca-Cola noted: 'That is the beauty of our business: no matter the time of day or the business climate, people will be thirsty and The Coca-Cola Company will be there to refresh them'. ${ }^{11}$ Companies focused on leveraging economies that experienced limited impacts during the Great Recession: India, China, Latin America and Africa. ${ }^{12-14}$ Nestlé's 'unmatched geographic presence meant that we were able to ride the wave of recovery in emerging markets, whilst benefiting from the resilience of North American consumers'. ${ }^{13}$ Nestlé also developed 'popularly positioned 
products' in smaller individual packages that cost less for the consumer than traditional products sold in Europe and North America. ${ }^{13}$

Second, Coca-Cola, Nestlé and PepsiCo positioned themselves during the Great Recession as partners to government and civil society; this was especially true during the economic recovery period. Nestlé emphasised the need for such partnerships, with 'economic, social and environmental challenges that we face today [being] too complex to be tackled by one organisation alone' ${ }^{15}$ As unemployment rates rose, standard hiring practices were recast as charitable actions in service of economic growth, ${ }^{16}$ with Nestlé claiming to have 'a positive impact on human rights by creating and supporting economic activity-helping people live to an acceptable standard by ensuring fair wages, working hours and working conditions'. ${ }^{15}$

The world's largest food and beverage companies seem to be following Sir Winston Churchill's advice: 'Never let a good crisis go to waste'. These companies are using the same response to the current pandemic because it has worked for them in the last economic crisis, the Great Recession. van Schalkwyk and colleagues noted that 'the exploitation of disasters by those in powerful positions is not a modern phenomenon'. 'Coca-Cola, PepsiCo and Nestlé today remain among the world's largest companies. ${ }^{6}$ Coca-Cola promised its shareholders in July 2020 , in the context of the pandemic: 'we will emerge stronger. We will win more consumers, gain share, maintain strong system economics, strengthen our impact across our stakeholders and equip our organization to win in the future'. ${ }^{17}$

Large food and beverage companies, many founded in the late 19th and early 20th centuries, have continued to expand despite, or perhaps because of, a long history of punctuated crises. Using Klein's theory of disaster capitalism, ${ }^{18}$ we predict that the recovery period from the COVID-19 pandemic (as well as future crises) will be exploited as an opportunity for food and beverage companies to (1) increase the consolidation of market share within a few transnational companies, (2) fuel the penetration of ultraprocessed products into LMIC markets, and (3) improve public relations and build strategic alliances with governments and civil society actors who might otherwise not collaborate with the industry.

Since the beginning of the COVID-19 pandemic, transnational food and beverage companies have deployed strategies similar to those used during the Great Recession. One possible difference might be the current, heavy investments in corporate philanthropy (also called 'corporate social responsibility') across the globe, which was less pronounced in the past. ${ }^{13}$ As some countries are now reaching a phase of economic recovery, transnational food and beverage companies will likely continue to call for such partnerships with governmental and nongovernmental organisations. ${ }^{13}$ More so than at other times, the public health community should redouble its efforts to monitor this industry using past episodes of crisis to anticipate industry actions through counterstrategies that buffer population health into the future, particularly in LMICs.

Twitter Melissa Mialon @MIALONMelissa

Contributors $\mathrm{MM}$ is a food engineer with a $\mathrm{PhD}$ in nutrition. She conducts research on the political practices of the food and alcohol industries. She conceived the study, led data collection and analysis and the drafting of the manuscript. She is the guarantor of the article. IP is a clinical psychologist by training and a public health researcher. She has experience working on the business practices of the alcohol industry in the Americas. LS is a professor of health policy who works on the social determinants of health and lifestyle risk factors, such as alcohol and poor diet, which influence chronic disease and health inequality. IP and LS made a substantial contribution to data analysis and revised the manuscript critically for important intellectual content. The corresponding author attests that all listed authors meet authorship criteria and that no others meeting the criteria have been omitted. Our sources of information include company reports (annual reports and corporate social responsibility reports) and documents (such as those posted on the UN Global Compact website) from the top three publicly traded global food and beverage companies (Coca-Cola, Nestle and PepsiCo)

Funding This study was funded by the University of North Carolina at Chapell Hill (UNC), USA, with a grant from Bloomberg Philanthropies. The authors are solely responsible for the opinions, hypotheses, and conclusions or recommendations expressed in this comment, and they do not necessarily reflect UNC's vision.

Competing interests None declared.

Patient consent for publication Not applicable.

Provenance and peer review Not commissioned; externally peer reviewed.

Data availability statement Documents were retrieved from publicly available, online sources--but not a single repository.

Open access This is an open access article distributed in accordance with the Creative Commons Attribution Non Commercial (CC BY-NC 4.0) license, which permits others to distribute, remix, adapt, build upon this work non-commercially, and license their derivative works on different terms, provided the original work is properly cited, appropriate credit is given, any changes made indicated, and the use is non-commercial. See: http://creativecommons.org/licenses/by-nc/4.0/.

Author note The corresponding author is on maternity leave. For time-sensitive inquiries, also contact the senior author: laura.schmidt@ucsf.edu.

\section{ORCID iDs}

Melissa Mialon http://orcid.org/0000-0002-9883-6441

Laura Schmidt http://orcid.org/0000-0003-4346-7260

\section{REFERENCES}

1 van Schalkwyk MC, Maani N, McKee M. Public health emergency or opportunity to profit? the two faces of the COVID-19 pandemic. Lancet Diabetes Endocrinol 2021;9:61-3.

2 The Lancet Diabetes Endocrinology. Food policies: in times of COVID-19 and beyond. Lancet Diabetes Endocrinol 2021;9:319.

3 Collin J, Ralston R, Hill S, et al. Signalling Virtue, Promoting Harm: Unhealthy commodity industries and COVID-19 [Internet]. NCD Alliance, SPECTRUM, 2020. Available: https://ncdalliance.org/sites/ default/files/resource_files/Signalling Virtue\%2C Promoting Harm Sept2020_FINALv.pdf

4 International Baby Food Action Network, International Code Documentation Centre. Breaking the rules, stretching the rules 2017: evidence of violations of the International Code of marketing of Breastmilk substitutes and subsequent resolutions. Penang, 2017.

5 WHO Foundation. WHO Foundation Twitter [Internet]. Twitter, 2021. Available: https://twitter.com/thewhof/status/1379841393452023808 [Accessed 8 May 2021].

6 Fortune. Fortune Global 500 [Internet], 2020. Available: https:// fortune.com/global500/ [Accessed 28 Nov 2020].

7 The Coca-Cola Company. 2009 annual review. Atlanta, Georgia, USA; 2009.

8 Nestlé. Management report 2008. Cham and Vevey (Switzerland); 2009.

9 PepsiCo. 2008 annual report. Purchase, NY, USA; 2009.

10 PepsiCo. Pepsico, Inc., form 10-K annual report, for the fiscal year ended December 27, 2008. Purchase, NY, USA; 2009. 
11 The Coca-Cola Company. 2008 annual review. Atlanta, Georgia, USA; 2008.

12 PepsiCo. PepsiCo, Inc. Form 10-K annual report for the fiscal year ended December 25, 2010. Purchase, NY, USA; 2011.

13 Nestlé. Annual report 2009. Cham and Vevey (Switzerland); 2010.

14 Nestlé. Annual report 2010. Cham and Vevey (Switzerland); 2011.

15 Nestlé. Nestlé in society | creating shared value and meeting our commitments 2012 | full report. Vevey (Switzerland); 2012.
16 Nestlé. Nestlé in society - creating shared value and meeting our commitments 2013. Vevey (Switzerland); 2013.

17 The Coca-Cola Company. The Coca-Cola Co. (KO) Q2 2020 earnings call. Atlanta, Georgia, USA; 2020.

18 Klein N. The Shock Doctrine [Internet]. Penguin; 2008: 576. / books/55595/the-shock-doctrine/9780141024530 [Accessed 22 Apr 2021]. 